\title{
Iodine status of pregnant women in Northern Cyprus
}

\author{
Umut Mousa ${ }^{1}$, Hasan Sav ${ }^{1}$, Osman Köseoğluları ${ }^{2}$, Murat Faik Erdoğan ${ }^{3}$ \\ ${ }^{1}$ Department of Endocrinology and Metabolism, Dr. Burhan Nalbantoğlu State Hospital, Nicosia, Cyprus \\ ${ }^{2}$ Marmara Clinic, Lefkoşa, Cyprus \\ ${ }^{3}$ Department of Endocrinology and Metabolism, Ankara University School of Medicine, Ankara, Turkey
}

To the Editor,

Iodine requirements increase in pregnancy (1). The World Health Organization and U.S. Institute of Medicine suggest a daily intake of $250 \mu \mathrm{g} / \mathrm{d}$ (2) and $220 \mu \mathrm{g} / \mathrm{d}$, respectively, for pregnant women (3). A median urinary iodine concentration below $150 \mu \mathrm{g} / \mathrm{L}$ reflects insufficient iodine intake in a pregnant population (2).

Before the introduction of iodized salt to our country in 1999, we performed a study in 625 school-age children and found that the median (minimum-maximum) urinary iodine concentration was 120 (11-900) $\mu \mathrm{g} / \mathrm{L}$ (4). In 2003, we conducted a monitoring study in 450 school-age children. The median (minimum-maximum) urinary iodine concentration increased to 139.5 (16-770) $\mu \mathrm{g} / \mathrm{L}$ (unpublished data). Thus, our region was considered to be iodine-replete. We have no data regarding pregnant subjects. The aim of this study was to analyze the urinary iodine concentration in a cohort of pregnant women residing in Northern Cyprus.

The study was approved by "B. Nalbantoglu Ethical Committee, Nicosia, Cyprus" in which 258 pregnant inhabitants in all trimesters were included between January and June 2016.

We administered a questionnaire and obtained morning iodine samples from the study population until laboratory analysis performed in Ankara University, Medical School, Endocrinology Laboratory, which is a part of the Ensuring the Quality of Urinary Iodine Procedures program conducted by the Centers for Disease Control and Prevention (USA).

Subjects using iodine supplements or iodine-containing multivitamins were not eligible for this study.

According to the World Health Organization criteria for iodine nutrition during pregnancy, participants were divided into five groups: adequate iodine (urinary iodine concentration: 150-249 $\mu \mathrm{g} / \mathrm{L}$ ), mild deficiency (urinary iodine concentration: 100-150 $\mu \mathrm{g} / \mathrm{L}$ ), moderate deficiency (urinary iodine concentration $<100$ $\mu \mathrm{g} / \mathrm{L}$ ), severe deficiency (urinary iodine concentration $<50 \mu \mathrm{g} / \mathrm{L}$ ), and more than adequate or excessive (urinary iodine concentration $\geq 250 \mu \mathrm{g} / \mathrm{L}$ ) groups. General characteristics of the study group are presented in Table 1 . The mean age of the study group was $28.62 \pm 5.8$ years (17-46). The median (minimum-maximum) urinary iodine concentration was $110(8-450) \mu \mathrm{g} / \mathrm{L}$. The median urinary iodine concentration were similar in all three trimesters (1st trimester 108 $\mu \mathrm{g} / \mathrm{L}, 2$ nd trimester $112 \mu \mathrm{g} / \mathrm{L}, 3$ rd trimester $116 \mu \mathrm{g} / \mathrm{L} ; \mathrm{p}=0.392$ )

The median urinary iodine concentration was $113 \mu \mathrm{g} / \mathrm{L}$ among subjects using iodized salt and $77 \mu \mathrm{g} / \mathrm{L}$ in subjects using noniodized salt $(\mathrm{p}=0.330)$. The median urinary iodine concentration was 114 $\mu \mathrm{g} / \mathrm{L}$ among subjects who restricted their salt intake and $106 \mu \mathrm{g} / \mathrm{L}$ among those who did not restrict their salt intake $(p=0.273)$. The

\begin{tabular}{lc}
\multicolumn{2}{c}{ TABLE 1. General characteristics of the study } \\
population
\end{tabular}

Address for Correspondence: Dr. Umut Mousa, Department of Endocrinology and Metabolism, Dr. Burhan Nalbantoğlu State Hospital, Nicosia, Cyprus e-mail: umutmousa@yahoo.co.uk ORCID ID: orcid.org/0000-0002-8078-9376

Received: 8 May $2018 \quad$ Accepted: 6 September 2018 • DOI: 10.4274/balkanmedj.2018.0679

Available at www.balkanmedicaljournal.org

Cite this article as:

Mousa U, Sav H, Köseoğluları O, Erdoğan MF. Iodine status of pregnant women in Northern Cyprus. Balkan Med J 2018;35:449-50

${ }^{\circ}$ Copyright 2018 by Trakya University Faculty of Medicine / The Balkan Medical Journal published by Galenos Publishing House. 
median urinary iodine concentration was $102 \mu \mathrm{g} / \mathrm{L}$ for those with a history of spontaneous abortion and $111 \mu \mathrm{g} / \mathrm{L}$ for those with no abortion history $(\mathrm{p}=0.293)$.

This study is the first to report on the iodine status of pregnant women in Northern Cyprus. The urinary iodine concentration value in this population is insufficient for pregnant women according to World Health Organization guidelines. Many studies have reported insufficient urinary iodine concentration in pregnancy, even in areas of iodine sufficiency (5).

Routine iodine supplementation during pregnancy is recommended by many authorities worldwide, even in iodine-sufficient areas (3). Significantly low maternal iodine intake during pregnancy can lead to irreversible neurological damage and cretinism (1-5). Maternal iodine insufficiency has been previously linked to abortion and preterm birth (1-5). However, in this study the median urinary iodine concentration was similar in subjects with and without a previous history of abortion.

We conclude that, although Northern Cyprus was proven to be an iodine-replete population, iodine nutrition is insufficient among pregnant women, and because more than $50 \%$ of our subjects have urinary iodine concentration $<100 \mu \mathrm{g} / \mathrm{L}$, we need to advocate for the use routine supplementation of iodine at $100-150 \mu \mathrm{g} / \mathrm{d}$ together with iodized salt usage.

Conflict of Interest: No conflict of interest was declared by the authors.

Financial Disclosure: No financial disclosure was declared by the authors.

\section{REFERENCES}

1. Zimmermann MB. The effects of iodine deficiency in pregnancy and infancy. Paediatr Perinat Epidemiol 2012;26(Suppl 1):108-17.

2. Assessment of iodine deficiency disorders and monitoring their elimination, 3rd ed. Geneva: World Health Organization, 2007.

3. Alexander EK, Pearce EN, Brent GA, Brown RS, Chen H, Dosiou C, et al. 2017 Guidelines of the American Thyroid Association for the Diagnosis and Management of Thyroid Disease During Pregnancy and the Postpartum. Thyroid 2017;27:315-89.

4. Erdogan G, Sav H, Erdogan MF. Iodine status and thyroid volumes of school age children from Northern Cyprus. J Endocrinol Invest 2000;23:74-7.

5. Harding KB, Peña-Rosas JP, Webster AC, Yap CM, Payne BA, Ota E, et al. Iodine supplementation for women during the preconception, pregnancy and postpartum period. Cochrane Database Syst Rev 2017;3:CD011761. 